\title{
Features of the Creative Abilities' Formation of Undergraduates in the Context of the Requirements of Professional Standards in the Field of Physical Education and Sports
}

\author{
Mikhaylova Darya Alexandrovna \\ Department of Management and Social Technologies' Institute, docent of Theory and Methods of Physical Culture's \\ Department of Martial Arts and Non-Olympic Sports' Faculty \\ The Federal State Budget Educational Institution of the Higher Education «National State University of Physical Culture, Sport \\ and Health named after P. F. Lesgaft, Saint-Petersburg» \\ Saint-Petersburg, Russia \\ d-samuray@yandex.ru
}

\begin{abstract}
The article considers the scientific problem of the contradiction between the economically and socially determined need for the formation of creative abilities among professionals in the field of physical education and sports and the lack of developed technologies for the implementation of such a formation in the course of undergraduate training. As a result of a survey of trainers and leaders of organizations in the field of physical education and sports, it was found that the percentage of need for all the creative abilities considered is higher than the percentage of the levels of their formation, both after studying at a university and during personal experience of professional activity, like with trainers, and among leaders of organizations in the field of physical education and sports. This fact proves that in the course of obtaining a higher education these issues are not considered or are considered insufficiently, while immersion in activities and work in the profession cannot fully compensate for these gaps. Thus, we have the right to assert that in the field of physical education and sports, within the framework of the next generation of federal state educational standards of higher education, it is proposed to include such competencies, which correlate with the formation of creative abilities among graduate students.
\end{abstract}

Keywords: educational standard, formation, creative abilities, magistracy, staff

\section{INTRODUCTION}

\section{A. Definition of concepts}

Highest-achivements' sports - a direction in the social practice of sports, orienting athletes to absolute sports results (achievements) and a steady increase in their level, subject to many years of daily expenditure of time and effort on sports' activities and subject to outstanding sports' giftedness of dealings $[1,2]$.

Creativity is an activity, the purpose of which is to produce the most adequate to the considered stage and, accordingly, the praxiologically correct (optimal) solution to the actual problem, the implementation options for which may include: creation of a fundamentally new product; adoption of an original or identification of an implicit (non-standard - nonobvious for stereotypical thinking) decision; transformation of the known into the extraordinary due to the use of an approach that is not characteristic of this case (the activity is optimizing in nature) $[3,4]$.

One of the key phenomena of the theory of creativity is giftedness: 1) as a construct, which determines high success in the activity; 2) as hypertrophied inclinations (natural giftedness or giftedness in the narrow sense of the word); 3 ) as a hypertrophied ability (cultural giftedness or giftedness in the broad sense of the word, acquired in an activity, but based on inclinations, depending on their level) [3, 4].

The presence in the definition of the concept of "highestachivements" sports" of the concept of "sports" giftedness" as a determining factor for the success of the activity, that is, a factor in the level of sports' achievements and the prerequisites for the scale of sports' records, allows us to state that highest-achivements' sports are a sphere of creative activity in connection with that one of the key concepts in the theory of creative activity is "giftedness" (a hereditary factor considered by sports' genetics [5]). 


\section{LITERATURE REVIEW}

\section{A. Determining the relevance of the study.}

Fair assessment in the education system is always a problem. This happens, at least due to the fact that educational programs do not include in full the disciplines that teach future educators strategies and assessment technologies. On the one hand, evaluation should be continuous. On the other hand, it is important what characteristics (indicators) are evaluated, and by what criteria, the formation of each indicator is evaluated. Thus, the main responsibility concerns the result of the assessment, and the main thing is to identify ways to improve the quality of both education and assessment systems [6]

So at the present stage, educators offer a comprehensive assessment system, adapted to the tasks of sustainable development programs of society. The world pedagogical community offers multidimensional systems for assessing competency, which link impact, process, results, observation and improvement of educational programs. Such a comprehensive assessment makes it possible to take into account both the degree of achievement of the goals of educational management and the development of educational potential, and to evaluate the sustainability of the development of the educational system. Of particular importance is the assessment of the degree of influence of national education systems on the long-term results and consequences of the development of national economic systems, which is of particular importance in ensuring interdisciplinary and interagency interactions, while mobilizing resources for improving socio-economic development programs [7].

Today, educators attach great importance to the formation of the general competencies of specialists, the achievement of which is based on the enthusiasm and motivation of both educators and students. However, the problem is that the amount of hours provided for this is too small [8].

In particular, the formation of a culture of integrity is extremely relevant. Obviously, such broader attributes of integrity, as personal and social responsibility, as well as honesty, both of a citizen and a specialist, determine the moral and ethical level of the society in which we live, and they allow the transmission of cultural values to future generations [9].

In other words, academic values are considered as a kind of standard that allows you to maintain society at the level of civilization that it needs and is inherent in, increasing the relevance of higher education, on the one hand, and managing the ratings of educational organizations, on the other hand [10]. In the context of the modern understanding of the human phenomenon in the philosophy of education, its place and role in the education system, the analysis of humanistic foundations and ideological bases of modern education, this fact takes on particular urgency [11].

It is especially interesting to consider such issues in the light of the analysis of indicators used to assess the reputation and ratings of educational organizations that determine the quality of higher education in general, its fate, the consequences for the development and improvement of a scientific and pedagogical institute [12].

However, from our point of view, for a specialist, of course, not only general, but also special competencies (abilities) that determine his professional qualities, suitability and effectiveness are important.

\section{B. Highest-achivements' sports as a sphere of creative activity: theoretical and methodological discourse on a scientific problem.}

So, the leading professional (special) competence, in our opinion, is the ability to creatively solve situations that arise in a variety of professional activities.

Of course, this is extremely important for sports activities, due to the fact that highest-achivements' sports are considered as a sphere of creative activity. Therefore, both athletes and coaches must have special creative abilities.

In other words, pedagogical creativity in modern highestachivements' sports is considered as an innovative pedagogical technology that allows you to control the athlete's creativity, bringing it closer to achieving the highest sports results [13]. And sports' creativity can be considered as a mechanism for solving difficulties and problems that arise during sports' training [14]. To some extent, it is an instrument of psychological correction and an activator of sports motivation [15]. On the other hand, creativity is manifested by the athlete during the development of motor actions, in particular, both when adapting to a new action during the formation of a new functional system in the body, and in the process of improving the ability to perform selected motor actions in various conditions and non-standard situations [16].

Thus, it is logical that pedagogical creativity in physical education, in turn, allows you to manage the training of specialists (bachelors and masters), updating the formation of professional abilities that they can use to optimally solve various non-standard situations and tasks of immediate operational work.

A contextual analysis of Russian dissertational researches for the degree of Doctor of Sciences on the subject of highestachivements' sports as a sphere of creative activity showed that the main scientific problems, the solution of which attracted researchers in this field, are the following:

- the problem of clarifying the correct understanding of the content and using in the theory of physical education and sports of concepts - variability, motor talent and abilities, as well as the development of a new concept for managing the training process using the concepts of a motor task and its characteristics (V. V. Gozhin) [17];

- the problem of the structure and content of sports' selection and its component - diagnostics of sports' giftedness, as well as rational planning of physical education of each teenager in accordance with his individual inclinations and natural capabilities, 
field $[21,22,23,24,25,26,27]$, and from the content of professional standards (Tables II, III and IV) [28, 29], suggest that the specialist should be able to quickly and efficiently solve any non-standard situations, explain his actions if necessary, apply creative abilities in the process of managing the pedagogical process, are excluded from the mandatory requirements of educational standards in this field. The responsibility for the formation of these abilities is secretly transferred to educational organizations, which provokes the formation of staff of different competencies: both effective and different. This approach does not hold water.

TABLE II. GENERALIZED LABOR FUNCTIONS OF PROFESSIONAL STANDARDS RELATED TO THE FORMATION OF SPECIAL CREATIVE ABILITIES IN THE FIELD OF PHYSICAL EDUCATION AND SPORTS

Research methods (according to the classification of B. G. Ananyev in the modification of E. R. Yakhontov [20] for sports and pedagogical research and the author's supplement): comparative method, case studies, survey method (in the form of questionnaire), frequency analysis, analysis of contingency tables, genetic method, theoretical modeling.

\section{DOCUMENTS' ANALYSIS RESULTS}

A comparative analysis of Russian educational standards in the field of physical education and sports over the past ten years allows us to conclude that documents of this kind are being modernized towards simplification and primitivization (Table I).

TABLE I. RUSSIAN FEDERAL STATE EDUCATIONAL STANDARDS OF HIGHER EDUCATION FOR THE MASTER'S LEVEL AND THE FORMATION OF SPECIAL CREATIVE ABILITIES IN THE FIELD OF PHYSICAL CUlturE AND SPORTS AS COMPETENCIES

\begin{tabular}{|c|c|c|}
\hline \multirow{2}{*}{$\begin{array}{c}\text { Russian Federal State } \\
\text { Educational Standards } \\
\text { of Higher Education }\end{array}$} & \multicolumn{2}{|c|}{ Creative Competences } \\
\hline & Definition & Kind \\
\hline $\begin{array}{ll}\text { Federal } & \text { State } \\
\text { Educational } & \text { Standard of } \\
\text { Higher } & \text { Professional } \\
\text { Education } & \end{array}$ & $\begin{array}{l}\text { is able to produce creative } \\
\text { ideas, theoretically } \\
\text { substantiate them, referring } \\
\text { to modern scientific views, } \\
\text { correctly, concisely and } \\
\text { reasonably uphold, } \\
\text { translate into professional } \\
\text { activities in temporary } \\
\text { detention facilities }\end{array}$ & $\begin{array}{l}\text { profile } \\
\text { professional } \\
\text { competence } \\
\text { PPK-1 }\end{array}$ \\
\hline \multirow{2}{*}{$\begin{array}{l}\text { Federal State } \\
\text { Educational Standard of } \\
\text { Higher Education }\end{array}$} & $\begin{array}{l}\text { ability to make non- } \\
\text { standard decisions }\end{array}$ & $\begin{array}{l}\text { general } \\
\text { cultural } \\
\text { competency } \\
\text { OK-8 }\end{array}$ \\
\hline & $\begin{array}{l}\text { ability to solve non- } \\
\text { standard problems in the } \\
\text { process of training athletes }\end{array}$ & $\begin{array}{l}\text { professional } \\
\text { competency } \\
\text { PK-12 }\end{array}$ \\
\hline $\begin{array}{l}\text { Federal State } \\
\text { Educational Standard of } \\
\text { Higher Education of } \\
\text { Generation 3+ }\end{array}$ & $\begin{array}{l}\text { the ability to solve non- } \\
\text { standard problems in the } \\
\text { process of training athletes }\end{array}$ & $\begin{array}{l}\text { professional } \\
\text { competency } \\
\text { PK-9 }\end{array}$ \\
\hline $\begin{array}{l}\text { Federal State } \\
\text { Educational Standard of } \\
\text { Higher Education of } \\
\text { Generation 3++ }\end{array}$ & \multicolumn{2}{|l|}{ no mandatory competencies } \\
\hline
\end{tabular}

In particular, the obvious requirements that follow, both from the results of modern Russian scientific research in this

\begin{tabular}{|l|l|l|l|}
\hline \multicolumn{2}{|c|}{$\begin{array}{c}\text { Professional Standard } \\
\text { "Trainer" }\end{array}$} & $\begin{array}{c}\text { Professional Standard "Leader of } \\
\text { Organization (Units of the Organization) } \\
\text { in the Field of Physical Culture and } \\
\text { Sports" }\end{array}$ \\
\hline $\begin{array}{l}\text { The } \\
\text { code }\end{array}$ & \multicolumn{1}{|c|}{ Definition } & \multicolumn{1}{|c|}{ The code } & \multicolumn{1}{|c|}{ Definition } \\
\hline G & $\begin{array}{l}\text { Leadership for } \\
\text { the } \\
\text { replenishment } \\
\text { and training of a } \\
\text { sports'reserve }\end{array}$ & $\begin{array}{l}\text { Leadership for sports' } \\
\text { training } \\
\text { Preparation of } \\
\text { the sports' team } \\
\text { of the Russian } \\
\text { Federation by } \\
\text { sport (sports } \\
\text { discipline, } \\
\text { group of sports } \\
\text { disciplines for } \\
\text { performances at } \\
\text { official and } \\
\text { international } \\
\text { sports } \\
\text { competitions }\end{array}$ \\
\hline
\end{tabular}


TABLE IV. EXAMPLES OF INDICATORS OF MASTERY OF LABOR

TABLE III. LABOR FUNCTIONS OF PROFESSIONAL STANDARDS (AND THEIR PROJECTS) RELATED TO THE FORMATION OF SPECIAL CREATIVE ABILITIES IN THE FIELD OF PHYSICAL CULTURE AND SPORTS

\begin{tabular}{|c|c|c|c|}
\hline \multicolumn{2}{|c|}{$\begin{array}{l}\text { Professional Standard } \\
\text { "Trainer" }\end{array}$} & \multicolumn{2}{|c|}{$\begin{array}{c}\text { Professional Standard "Leader of } \\
\text { Organization (Units of the Organization) } \\
\text { in the Field of Physical Culture and } \\
\text { Sports" }\end{array}$} \\
\hline $\begin{array}{l}\text { The } \\
\text { code }\end{array}$ & Definition & The code & Definition \\
\hline $\begin{array}{l}\mathrm{G} \quad / \\
01.7\end{array}$ & $\begin{array}{l}\text { Organization } \\
\text { and monitoring } \\
\text { of the } \\
\text { preparation of a } \\
\text { sports reserve } \\
\text { by type of sport } \\
\text { (sports } \\
\text { discipline, } \\
\text { group of sports } \\
\text { disciplines) }\end{array}$ & E / 01.7 & $\begin{array}{l}\text { Current planning of } \\
\text { sports training }\end{array}$ \\
\hline $\begin{array}{l}\mathrm{G} / \\
02.7\end{array}$ & $\begin{array}{l}\text { Management of } \\
\text { the system for } \\
\text { identifying } \\
\text { promising } \\
\text { athletes and } \\
\text { conducting } \\
\text { selection to } \\
\text { replenish the } \\
\text { sports' reserve } \\
\text { of the sports' } \\
\text { team of the } \\
\text { Russian } \\
\text { Federation for a } \\
\text { sport (sports' } \\
\text { discipline, a } \\
\text { group of sports' } \\
\text { disciplines), the } \\
\text { subject of the } \\
\text { Russian } \\
\text { Federation for a } \\
\text { sport (sports' } \\
\text { discipline, a } \\
\text { group of sport' } \\
\text { disciplines) }\end{array}$ & E / 04.7 & $\begin{array}{l}\text { Leadership training, } \\
\text { educational and } \\
\text { methodological } \\
\text { activities in the } \\
\text { implementation } \\
\text { sports' training }\end{array}$ \\
\hline $\begin{array}{l}\mathrm{H} / \\
01.7\end{array}$ & $\begin{array}{l}\text { Monitoring the } \\
\text { process of } \\
\text { selecting } \\
\text { athletes for the } \\
\text { sports' national } \\
\text { team }\end{array}$ & E / 06.7 & $\begin{array}{l}\text { Organization of control } \\
\text { and accounting of } \\
\text { sports' training }\end{array}$ \\
\hline $\begin{array}{l}\mathrm{H} / \\
02.7\end{array}$ & $\begin{array}{l}\text { Athletes } \\
\text { training's } \\
\text { management for } \\
\text { the sports' team }\end{array}$ & & \\
\hline $\begin{array}{l}\mathrm{H} \quad / \\
03.7\end{array}$ & $\begin{array}{l}\text { Management of } \\
\text { the competitive } \\
\text { activities of the } \\
\text { sports' team }\end{array}$ & & \\
\hline $\begin{array}{l}\mathrm{H} \quad / \\
04.7\end{array}$ & $\begin{array}{l}\text { Coordination } \\
\text { and control of } \\
\text { the work of } \\
\text { trainers, } \\
\text { specialists } \\
\text { involved in the } \\
\text { training of } \\
\text { athletes of the } \\
\text { sports' team }\end{array}$ & - & \\
\hline
\end{tabular}

FunCTIONS OF PROFESSIONAL STANDARDS (AND THEIR PROJECTS), RELATED TO THE Formation of SPECIAL CREATIVE ABILITIES IN THE FIELD OF PhysicAl CUlTuRE AND SPORTS: KNOWLEDGE, SKILls, LABOR ACTIONS / EXPERIENCE AS EDUCATIONAL ACHIEVEMENTS

\begin{tabular}{|c|c|c|c|}
\hline \multicolumn{2}{|c|}{$\begin{array}{c}\text { Professional Standard } \\
\text { "Trainer" }\end{array}$} & \multicolumn{2}{|c|}{$\begin{array}{l}\text { Professional Standard "Leader of } \\
\text { Organization (Units of the } \\
\text { Organization) in the Field of Physical } \\
\text { Culture and Sports" }\end{array}$} \\
\hline $\begin{array}{l}\text { The } \\
\text { code }\end{array}$ & Definition & The code & Definition \\
\hline \multicolumn{4}{|c|}{ Knowledge } \\
\hline \multirow[t]{2}{*}{$\begin{array}{l}\text { K_G } \\
/ \\
01.7\end{array}$} & $\begin{array}{l}\text { Factors affecting } \\
\text { the quality of } \\
\text { training of a sports' } \\
\text { reserve by sport, } \\
\text { ways to minimize } \\
\text { and eliminate the } \\
\text { negative } \\
\text { consequences of } \\
\text { the identified } \\
\text { factors }\end{array}$ & K_E / 01.7 & $\begin{array}{l}\text { Content and ratio of the } \\
\text { volume of the training } \\
\text { process by type of } \\
\text { preparation }\end{array}$ \\
\hline & $\begin{array}{l}\text { The system of } \\
\text { factors ensuring } \\
\text { the effectiveness of } \\
\text { the } \\
\text { reserve's training } \\
\text { system }\end{array}$ & - & \\
\hline \multicolumn{4}{|c|}{ Abilities } \\
\hline $\begin{array}{l}\text { A_G } \\
/ \\
01.7\end{array}$ & $\begin{array}{l}\text { To draw up } \\
\text { methodically } \\
\text { substantiated } \\
\text { recommendations } \\
\text { for trainers and } \\
\text { sportsmen } \\
\text { sports' national } \\
\text { teams for a sport } \\
\text { (sports' discipline, } \\
\text { a group of sports' } \\
\text { disciplines), for } \\
\text { specialists of } \\
\text { organizations } \\
\text { engaged in } \\
\text { activities in the } \\
\text { field of physical } \\
\text { culture and sports } \\
\text { on the organization } \\
\text { of training of a } \\
\text { sports' reserve, } \\
\text { advise them }\end{array}$ & A_E / 01.7 & $\begin{array}{l}\text { To substantiate the } \\
\text { motives of the decisions } \\
\text { made }\end{array}$ \\
\hline \multicolumn{4}{|c|}{ Labor action / experience } \\
\hline $\begin{array}{l}\mathrm{LA}_{-} \\
\mathrm{G} / \\
01.7\end{array}$ & $\begin{array}{l}\text { Development of } \\
\text { proposals for the } \\
\text { adjustment of } \\
\text { additional pre- } \\
\text { vocational } \\
\text { programs in the } \\
\text { field of physical } \\
\text { education and } \\
\text { sports, and sports' } \\
\text { training programs } \\
\text { in organizations } \\
\text { preparing a sports' } \\
\text { reserve }\end{array}$ & LA_E / 01.7 & $\begin{array}{l}\text { Development of a } \\
\text { strategy for planning } \\
\text { activities for sports' } \\
\text { training }\end{array}$ \\
\hline
\end{tabular}




\section{EMPIRICAL RESEARCH RESULTS}

Diagnostics of the relevance of applying creative abilities in the professional activities of trainers and leaders of organizations in the field of physical education and sports.

\section{A. Results from descriptive statistics (frequency analysis)}

In the course of a survey (questionnaire) of trainers, the relevance of the necessity for formation was identified, as well as the levels of formation of the following creative abilities in them:

- the ability "to plan (to propose and justify) options for successfully overcoming non-standard situations that arise in the training and competitive processes, showing special creative abilities" (creative ability CA_T_1);

- the ability "to explain in an accessible and exciting way non-standard / innovative solutions to problems arising in the training and competitive processes" (creative ability CA_T_2);

- the ability to "use the functions, methods and techniques of imagination in the management of improving the skills of athletes to perform selected motor actions" (creative ability CA_T_3).

During the survey (questionnaire) of the leaders of organizations in the field of physical culture and sports, the relevance of the necessity for formation, as well as the levels of formation of their following creative abilities, were revealed:

- the ability "to plan (to propose and justify) options for successfully overcoming non-standard situations that arise when managing the labor process in a sports' and athletic organization, showing special creative abilities" (creative ability CA_L_1);

- ability "to explain in an accessible and exciting way non-standard / innovative solutions to labor management problems in a sports' organization" (creative ability CA_L_2).

The assessment of the compliance of each statement with the respondent's opinion was carried out in points: from one point (with the least compliance) to five points (with the highest compliance). Then, for all respondents, the sum of the points scored by each statement (accumulated points) was revealed, and the percentage of the total points scored from the maximum possible to gain the sum of points for each statement was determined based on the number of respondents. The magnitude of this percentage for each statement and conclusions are drawn.

A survey of coaches and leaders of organizations in the field of physical education and sports allows us to recognize the validity of the following statements.

It was revealed (Figures 1, 2, and 3 ) that the percent of necessity for all the creative abilities considered is higher than the percentage of the level of their formation, both after studying at a university, and during the personal experience of professional activity, both among trainers and leaders of organizations in the field of physical education and sports. This fact proves that in the course of obtaining a higher education these issues are not considered or are considered insufficiently, while immersion in activities and work in the profession cannot fully compensate for these gaps.

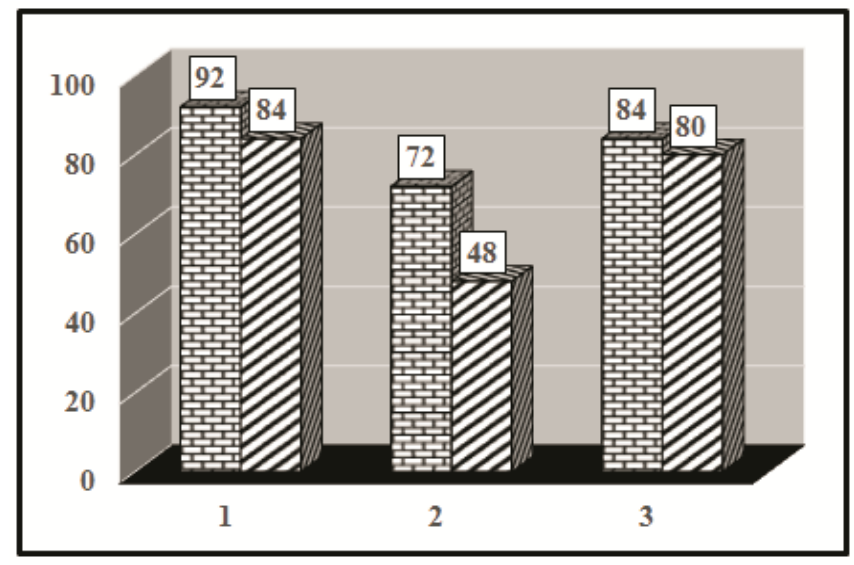

Fig. 1. The ability to plan creative solutions to professional tasks of trainers and leaders of organizations in the field of physical education and sports (\%), (filling "bricks" - trainers, filling "strips" - leaders of organizations in the field of physical education and sports; 1 - the need for ability, 2 - the formation of ability after graduation, 3 - the formation of ability at the present time in the course of personal experience)

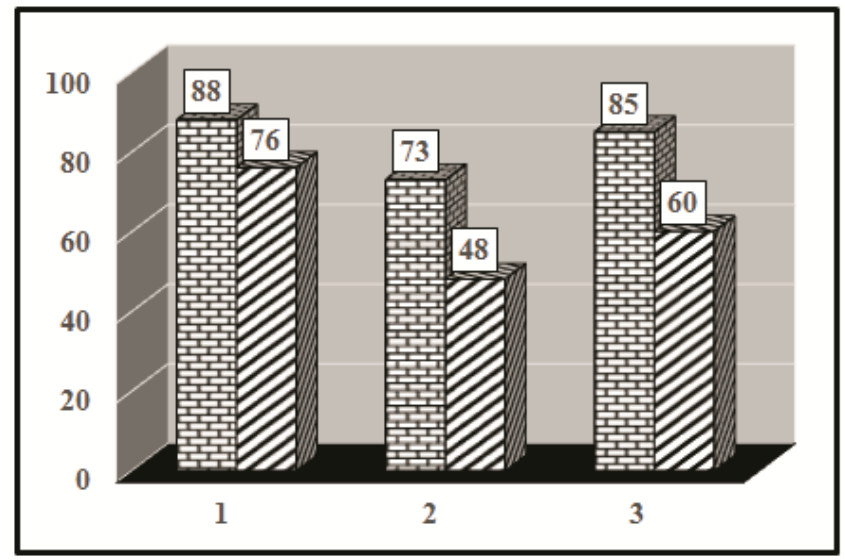

Fig. 2. The ability to explain creative solutions to professional problems with trainers and leaders of organizations in the field of physical education and sports (\%), (filling "bricks" - trainers, filling "strips" - leaders of organizations in the field of physical education and sports; 1 - the need for ability, 2 - the formation of ability after graduation, 3 - the formation of ability at the present time in the course of personal experience) 


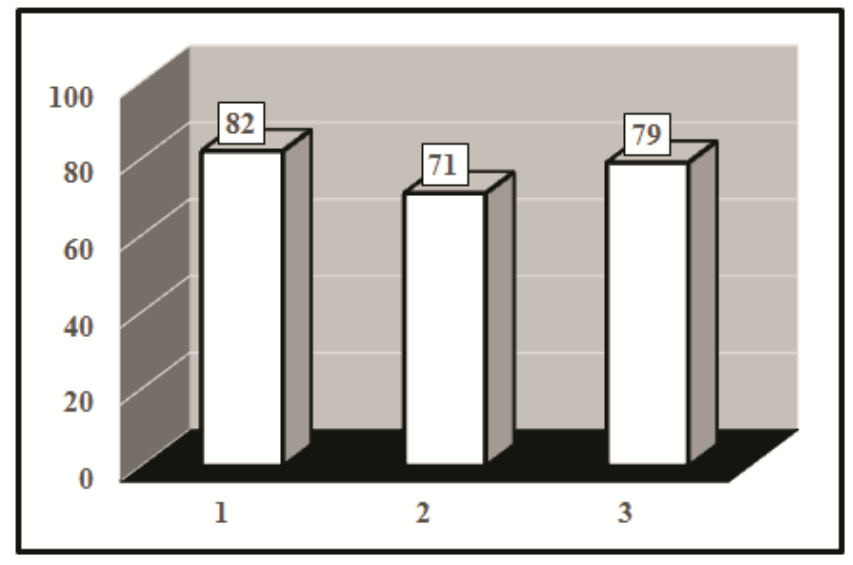

Fig. 3. The ability to use the functions, methods and techniques of imagination of trainers in the management of improving the skills of athletes to perform selected motor actions (\%), (1 - the need for ability, 2 - the formation of ability after graduation, 3 - the formation of ability at the present time in the course of personal experience)

\section{B. Results from explanatory statistics (analysis of contingency tables)}

It was established that the training category is interconnected with the labor experience, which is interconnected with the pedagogical experience and age of the trainer, the latter is interconnected with the level of education and the sports category of the trainer, while the level of education is interconnected with the gender of the trainer (Fig. 4).

The level of education of the trainer and the sports category are interrelated with his ability to plan actions in nonstandard situations, acquired through personal experience.

The sports category of a coach is interconnected with his ability to use the methods of imagination in treaching acquired through personal experience.

The gender of the trainer determines his ability to explain non-standard solutions of problems acquired during teaching at the university.

The ability to plan actions in non-standard situations and use the methods of imagination in teaching acquired through personal experience are determined by the understanding of the necessity to use them to ensure the required activity.

The ability to plan actions in non-standard situations is interconnected with the ability to explain non-standard solutions of problems, and the latter is interconnected with the ability to use the methods of imagination in teaching, and, in general, we are talking about the abilities acquired during teaching at the university and the abilities acquired during personal experience.

The ability to explain non-standard solutions of problems acquired during teaching at the university, on the one hand, is determined by the understanding of the necessity to use it to ensure the required activity, and, on the other hand, is interconnected with the ability to use imagination methods in teaching acquired through personal experience.

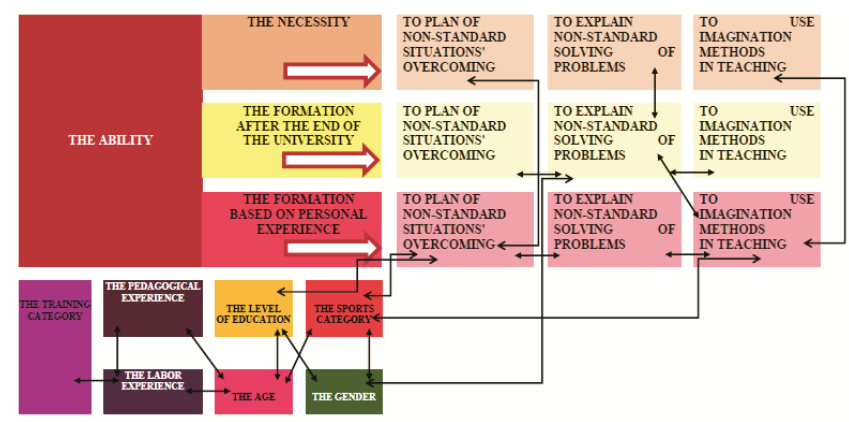

Fig. 4. Map of dependencies of special professional creative abilities of trainers from the main characteristics their social portrait (according to the analysis of contingency tables; $\mathrm{p} \leq 0.05$; by Pearson's $\mathrm{X}^{2}$ criterion / measure of connectedness d Somers)

\section{CONCLUSION}

The bachelor's program is designed to form students' knowledge, abilities, skills and value orientations to solve standard (typical) professional problems and situations. Master, in turn, involves the next step - preparation for solving non-standard (real, situationally arising) professional problems. Thus, the identified by us, the appropriate necessity for the formation of future staff in the field of physical culture and sports, the competencies of a creative attitude to professional activity, allowing successfully and efficiently solve the non-standard situations that accompany it, should be realized precisely in the magistracy.

\section{THE DISCUSSION OF THE RESULTS}

Proposals for improving federal state educational standards of higher education master's programs in the field of physical education and sports.

At first, in the direction of higher education preparation 49.04.03 Sports within the framework of the $3++$ generation are proposed to include the following competencies, related to the content of the discipline "Highest-achivements' sports as a sphere of creative activity" and to the formation of undergraduates' creative abilities, among the recommended professional competencies / self-determined professional competencies [are included by the educational organization based on the orientation (profile) of the master's program]:

- within the framework of orientation (profile), oriented to solving the problems of professional activity according to the coaching type - PC. Able to solve non-standard problems in the field of training athletes and during the preparation of a sports' team to perform at official sports' competitions of national, regional and local level;

- within the framework of orientation (profile), oriented to solving the problems of professional activity by organizational and managerial type - PC. Able to solve non-standard problems during the management of the replenishment and preparation of the sports' reserve, during the management of the preparation of the sports' team of the Russian Federation for performances at international competitions. 
Secondly, in the area of higher education preparation 49.04.01 Physical Education within the framework of the 3++ generation is proposed to include the following competencies related to the formation of undergraduates' creative abilities, among the recommended professional competencies / selfdetermined professional competencies [are included by the educational organization based on the orientation (profile) of the master's program]:

- within the framework of orientation (profile), oriented to solving the problems of professional activity by pedagogical type - PC. Able to solve non-standard problems in the field of pedagogical activity in vocational training, vocational education and additional professional education (correlates with the content of the discipline "Pedagogical creativity in the field of physical education");

- within the framework of orientation (profile), oriented to solving the problems of professional activity by organizational and managerial type - PK. Able to solve non-standard problems in the course of managing the activities and development of a fitness organization (correlates with the content of the discipline "Creativity of the leader of the organization in the field of physical education and sports").

\section{REFERENCES}

[1] Yu. F. Kuramshin, "Higher sporting achievements as an object of system analysis: monograph", second edition, supplemented, St. Petersburg: Russian State Pedagogical University named after A. I. Herzen, 2002, $148 \mathrm{p}$.

[2] V. N. Platonov, "The system of training athletes in Olympic sports. General theory and its practical applications", Moscow: Soviet Sport, 2005,820 p. (Illustrations 522 , tables 206, bibliography: pp. 800-820).

[3] D. A. Mikhailova, "Higher achievement sport as a sphere of creative activity in a retrospective of Russian scientific researches", a tutorial for students enrolled in the profile "Training of Highly Qualified Athletes in a Selected Sports", Teaching Direction 49.04.01 Physical Culture, National State University of Physical Culture, Sports and Health named after P. F. Lesgaft, St. Petersburg, 2015, 132 p. (Illustrations, bibliography: pp. 131-132).

[4] D. A. Mikhailova, "Sport of the highest achievements as a sphere of creative activity", a tutorial for students enrolled in the educational program "Training of Highly Qualified Athletes in a Selected Sports", Teaching Direction 49.04.01 Physical Culture, National State University of Physical Culture, Sports and Health named after P. F. Lesgaft, St. Petersburg, 2014, $244 \mathrm{p}$.

[5] E. B. Sologub and V. A. Taymazov. "Sports genetics: a tutorial", Moscow: Terra-Sport, 2000, $127 \mathrm{p}$.

[6] Francisco Gonçalves and Ágata Aranha, "Science evaluation methods in physical education courses", Avaliação: Revista da Avaliação da Educação Superior (Campinas), 2011, 16 (3), pp. 731-744. DOI: https://dx.doi.org/10.1590/S1414-40772011000300013.

[7] Peter H. Koehn, and Juha I. Uitto, "Evaluating sustainability education: lessons from international development experience", Higher Education, 2014, 67 (5), pp. 621-635. DOI: https://doi.org/10.1007/s10734-0139669-x.

[8] Mehrnaz Fahimirad, Pradeep K.Nair, and Kotamjani S. Shakib, "Integration and Development of Generic Competencies into Malaysian Higher Education Context: Review of the Literature (Version 2)", SageSubmissions, $26 \quad$ February 2019. DOI: https://doi.org/10.31124/advance.7763687.v2.
[9] Sarah Shi Hui Wong, Lim Wee Hun Stephen, and Kathleen M. Quinlan, "Integrity in and Beyond Contemporary Higher Education: What Does it Mean to University Students?", Frontiers in Psychology, 2016, 7, 1094 p. [Electronic resource]. Available at: https://www.frontiersin.org/article/10.3389/fpsyg.2016.01094.

[10] Gary R.S. Barron, "The Berlin Principles on Ranking Higher Education Institutions: limitations, legitimacy, and value conflict", Higher Education, 2017, 73(2), pp. 317-333. DOI: https://doi.org/10.1007/s10734-016-0022-z.

[11] Leena Kakkori and Rauno Huttunen, "The Sartre Heidegger Controversy on Humanism and the Concept of Man in Education", Educational Philosophy and Theory, 2012, 44 (4), pp. 351-365. DOI: https://doi.org/10.1111/j.1469-5812.2010.00680.x.

[12] Francis L. Collins and Gil-Sung Park, "Ranking and the multiplication of reputation: reflections from the frontier of globalizing higher education", Higher Education, 2016, 72 (1), pp. 115-129. DOI: https://doi.org/10.1007/s10734-015-9941-3.

[13] H. Duda and V. Khramov, "Creativity - Modern Requirement for Football Training", Human, Sport, Medicine, 2018, 18 (S), pp. 104-108. DOI: https://doi.org/10.14529/hsm18s14.

[14] J. Knijnik, R. Spaaij, and R. Jeanes, "Reading and writing the game: Creative and dialogic pedagogies in sports education", Thinking Skills and Creativity, 2019, 32, pp. 42-50. DOI: https://doi.org/10.1016/j.tsc.2019.03.005.

[15] E. Kuzmin, Y. Denisenko, A. Akhmetov, P. Chukhno, and I. Andruschishin, "Psychological and Pedagogical Conditions of Forming the Sport Motivation in Young Volleyball Players", Human, Sport, $\begin{array}{lllll}\text { Medicine, 2016, } 16 \text { (1), pp. 82-87. DOI: } & \end{array}$ https://doi.org/10.14529/hsm160114.

[16] V. Khramov, E. Shirshova, and E. Matova, "Providing Information about Movement Technique Using Cognitive Visualization", Human, Sport, Medicine, 2019, 19 (S1), pp. 99-105. DOI: https://doi.org/10.14529/hsm19s113.

[17] V. V. Gozhin, "Variability and motor talent in sports: abstract of the dissertation ... of a doctor of pedagogical sciences", Adygea's State University; Russian State Academy of Physical Culture, Maykop, 1998, $51 \mathrm{p}$.

[18] I. Yu. Sokolik, "Organizational and methodological foundations of the diagnosis of sports giftedness: abstract of the dissertation ... of a doctor of pedagogical sciences", Belarusian State Pedagogical University named after M. Tank, Moscow, 1998, 49 p.

[19] G. L. Drandrov, "Formation of readiness of students of faculties of physical culture for creative training in motor actions: abstract of the dissertation ... of a doctor of pedagogical sciences", Chuvash's State Pedagogical University named after I. Ya. Yakovleva, Omsk, 2002, 60 p.

[20] E. R. Yakhontov, "Methodology of sports and pedagogical research : a course of lectures", St. Petersburg State Academy of Physical Culture named after P. F. Lesgaft, St. Petersburg, 2002, pp. 42-50.

[21] V. F. Kostyuchenko, G. V. Rudenko, and Yu. A. Dubrovskaya, "Mass physical culture encouragement policies in context of national physical education and sports sector development strategy", Theory and Practice of Physical Culture, 2019, 3, pp. 38-39 [Electronic resource]. Available at: http://www.teoriya.ru/ru/node/10335.

[22] E. Ya. Mikhaylova, N. G. Zakrevskaya, E. V. Utisheva, and E. Yu.Komeva, "Social conceptions of physical education and sport professions: stratification approach", Theory and Practice of Physical Culture, 2019, 7, pp. 3-4 [Electronic resource]. Available at: http://www.teoriya.ru/ru/node/10802.

[23] T. V. Mikhaylova, "Sport Institution as basis for highly skilled personnel efficient training model", Theory and Practice of Physical Culture, 2016, 10, pp. 31-33 [Electronic resource]. Available at: http://www.teoriya.ru/ru/node/5532.

[24] M. Yu. Shchennikova and S. P. Evseev, "Professional Education in the Field of Physical Culture and Sport in Domestic and International Classifiers", Theory and Practice of Physical Culture, 2015, 1, pp. 14-18 [Electronic resource]. Available at: http://www.teoriya.ru/en/node/2808.

[25] M. Yu. Shchennikova and V. F. Kostyuchenko, "Professional education in national physical education and sports sector: evolution history and 
2016, 10, pp. 39-41 [Electronic resource]. Available at: http://www.teoriya.ru/ru/node/5535.

[28] Leader of the organization (unit of the organization) engaged in physical education and sports: professional standard [Electronic resource]. Available at: http://fgosvo.ru/uploadfiles/profstandart/ 05.008.pdf (Accessed: 20 November 2019).

[29] Trainer: professional standard [Electronic resource]. Available at: http://fgosvo.ru/uploadfiles/profstandart/05.003.pdf (Accessed: 20 November 2019). 